\title{
Unilateral acroparesthesias
}

\section{An unusual presentation of an acute stroke}

\author{
Timothy S. Lo, MD, MPH; and Olajide Williams, MD, MS
}

A 51-year-old right-handed man with hypertension but on no medications presented the day after the acute onset of numbness in the fingertips of his left hand. The acroparesthesias were limited to the distal aspects of the left third and fourth fingers. Neurologic examination revealed decreased sensation to light touch and pinprick in the left third and fourth distal phalanges. Two-point discrimination was impaired, and stereognosis and graphesthesia were not tested. The remainder of the examination was otherwise normal. Head CT was normal at presentation. The next day, diffusion-weighted MRI of the brain showed a restricted high signal area in the right somatosensory cortex. His symptoms re- solved over the course of 3 days. EKG, carotid ultrasonography, Holter monitoring, and transesophageal echocardiography were normal. He was discharged on aspirin and metoprolol.

Reports of pure sensory strokes by a cortical lesion are rare., ${ }^{1,2}$ Oftentimes, vague complaints of dysesthesias and paresthesias involving the fingertips and hands are attributed to compressive neuropathies such as carpal tunnel syndrome, cervical radiculopathy, a distal peripheral neuropathy, or hyperventilation syndromes. Contralateral sensory deficit involving the face, arm, and leg are attributed predominantly to thalamic lesions. When one or two parts of the contralateral side are involved, the local- ization of the lesion by clinical examination is more questionable. In this patient, the pure sensory stroke was due to a small infarction in the cortical territory of the middle cerebral artery caused, presumably, by an embolic source. Although no etiology for our patient's stroke was found on further evaluation, carotid embolic sources should be pursued, especially in the setting of recurrent paresthesias (figure).

\section{References}

1. Derouesne C, Mas JL, Bolgert F, Castaigne P. Pure sensory stroke caused by a small cortical infarct in the middle cerebral artery territory. Stroke 1984;15:660-662.

2. Kim JS. Pure sensory stroke: clinicalradiological correlates of 21 cases. Stroke 1992;23:983-987.
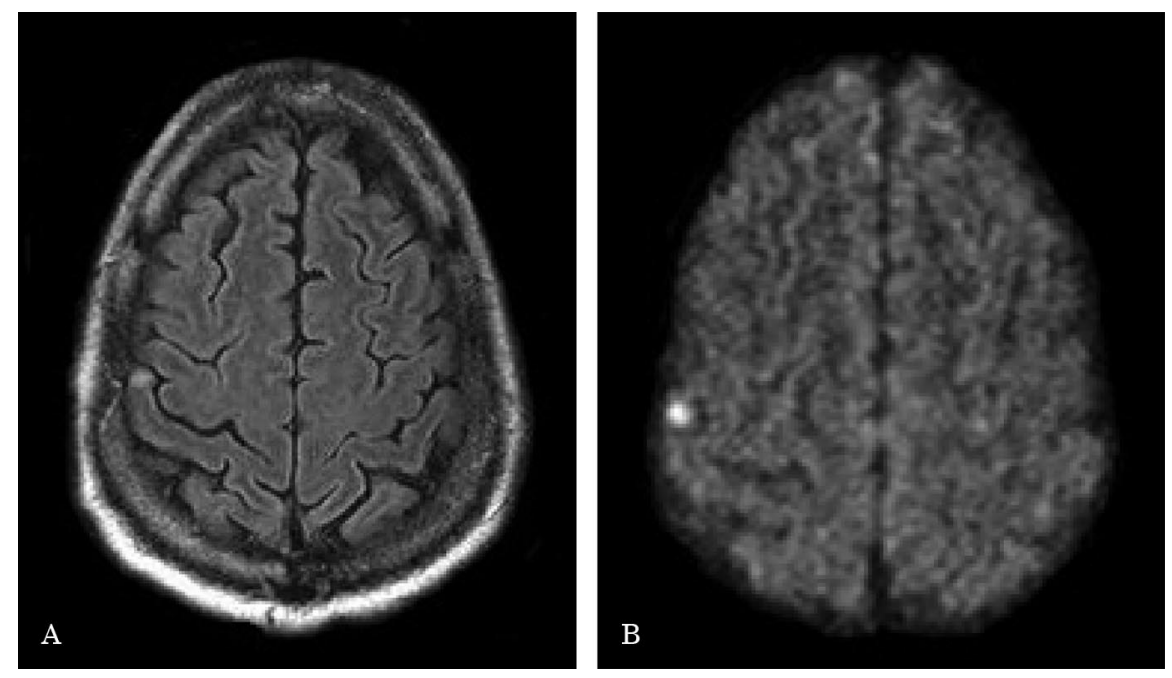

Figure. (A) Small focal area of increased signal in the right sensory cortex on axial T2-weighted MR image. (B) Diffusion-weighted imaging showing increased intensity in corresponding region consistent with acute infarction. 


\section{Neurology}

\section{Unilateral acroparesthesias: An unusual presentation of an acute stroke Timothy S. Lo and Olajide Williams \\ Neurology 2006;67;E9 \\ DOI 10.1212/01.wnl.0000230143.34760.64}

This information is current as of August 21, 2006

\section{Updated Information \& Services}

References

Subspecialty Collections

Permissions \& Licensing

Reprints including high resolution figures, can be found at: http://n.neurology.org/content/67/4/E9.full

This article cites 2 articles, 2 of which you can access for free at: http://n.neurology.org/content/67/4/E9.full\#ref-list-1

This article, along with others on similar topics, appears in the following collection(s):

All Cerebrovascular disease/Stroke

http://n.neurology.org/cgi/collection/all_cerebrovascular_disease_strok e

Central pain

http://n.neurology.org/cgi/collection/central_pain

Infarction

http://n.neurology.org/cgi/collection/infarction MRI

http://n.neurology.org/cgi/collection/mri

Information about reproducing this article in parts (figures,tables) or in its entirety can be found online at:

http://www.neurology.org/about/about_the_journal\#permissions

Information about ordering reprints can be found online:

http://n.neurology.org/subscribers/advertise

Neurology ${ }^{\circledR}$ is the official journal of the American Academy of Neurology. Published continuously since 1951, it is now a weekly with 48 issues per year. Copyright . All rights reserved. Print ISSN: 0028-3878. Online ISSN: 1526-632X.

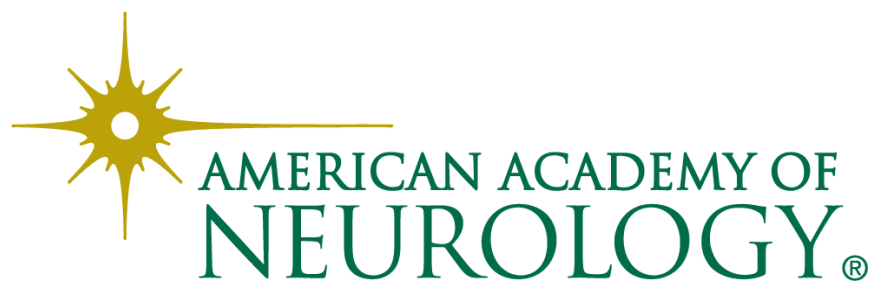

